\title{
Post-fire bryophyte establishment in a continental bog
}

\author{
Benscoter, Brian W. \\ Department of Plant Biology, Center for Ecology, Southern Illinois University-Carbondale, \\ Carbondale, IL 62901-6509, USA; Fax+1 6184533441; Email bbensc01@siu.edu
}

\begin{abstract}
Questions: What is the mechanism of bog ground layer colonization post-fire? Is species colonization stochastic or does facilitation occur?

Location: Boreal bog peatland near Crow Lake, Alberta, Canada.

Methods: Diaspore-addition treatments were applied in 2003 to autoclaved peat samples from high and low microtopographic positions within a recently burned bog. Colonization was assessed within the plots in 2005 and compared to control plots to determine treatment success and patterns of colonization.

Results: A significant degree of ground layer colonization was found two years after fire, with Polytrichum strictum dominating the site. Colonization was greater in low (wet) plots, although only P. strictum and Sphagnum angustifolium had significant colonization. No effect of diaspore addition was observed and Sphagnum was only found in conjunction with P. strictum.

Conclusions: Environmental conditions and species life history strategy are more important than diaspore availability for post-fire colonization. True mosses (e.g.P. strictum) appear to facilitate Sphagnum colonization.
\end{abstract}

Keywords: Colonization; Diaspore; Facilitation; Polytrichum; Sphagnum.

Nomenclature: Vitt et al. 1988.

\section{Introduction}

Environmental conditions play an important role in community composition, regardless of whether neutral processes (Hubbell 2001) or competitive interactions (Hutchinson 1958; Tilman 1982, 1994) are involved (Kneitel \& Chase 2004). In heterogeneous environments, community diversity is greater because the wide range of microhabitats allows for the simultaneous existence of species spatially due to differences in the fundamental niche among species (Hutchinson 1958; Whittaker 1972). Furthermore, in spatially structured habitats with a mosaic of environmentally similar but spatially distinct patches, functionally equivalent species can coexist due to stochastic distribution events (Tilman 1994; Hurtt \& Pacala 1995; Brokaw \& Busing 2000; Hubbell 2005).

Environmental conditions are also important during colonization following disturbance. If species establishment is a neutral process (i.e., not affected by competition) and diaspores are not limiting, then community structure is solely the result of environmental conditions (Cottenie 2005). In this case, differences in species' biotic tolerances and establishment requirements (the regeneration niche; Grubb 1977) should determine establishment success and patterns of colonization (Kimmerer \& Young 1996). However, the facilitation model of succession (Connell \& Slatyer 1977) stresses the importance of environmental modification by one species enabling the establishment of another. If facilitation is important, then the proportional occurrence of two species simultaneously should be greater than that of a later successional species alone soon after disturbance.

Understanding ground layer re-establishment following disturbance is particularly important in boreal bogs due to their role as a carbon sink. Fire is the dominant disturbance in western Canadian peatlands, consuming $1850 \mathrm{~km}^{2}$ annually (Turetsky et al. 2004) and removing the surface vegetation and underlying peat to varying degrees during combustion (Benscoter $\&$ Wieder 2003). Because the vast majority of carbon sequestration in bogs results from production of the ground layer bryophytes, return of the ground layer vegetation following disturbance is vital to functional 
recovery of bogs and ecosystem processes.

Mechanisms of bryophyte regeneration and colonization have been well documented on bare peat (Campeau \& Rochefort 1996; Smolders et al. 2003) and from within the peat column (Clymo \& Duckett 1986; Faubert \& Rochefort 2002) following horticultural peat harvest. However, colonization following natural disturbance, particularly fire, is poorly documented. Fire creates different edaphic conditions than peat harvesting through heterogeneous combustion severity (Benscoter \& Wieder 2003) and surface deposition of charcoal, so the vegetation response should be different as well (Benscoter et al. 2005).

Diaspores for bryophyte colonization can originate in situ (buried spores, vegetative propagules) or ex situ from aerial diaspore deposition (Clymo \& Duckett 1986; Campbell et al. 2003; Ross-Davis \& Frego 2004). Availability of diaspores does not appear to limit bryophyte establishment in boreal ecosystems (Rydin \& Barber 2001). Ross-Davis \& Frego (2004) found that regional and global diaspore dispersal deposits a far greater number of species on harvested boreal forest floors than were found in the extant community or the buried diaspore bank. For peatlands, the regional and local species pools are identical due to the species-limiting environment found there, particularly in bogs (Rydin \& Barber 2001). The Sphagnum species typically dominating bogs are capable of regenerating from fragments (Clymo \& Duckett 1986; Faubert \& Rochefort 2002) and also readily disperse spores, even for great distances (Rydin \& Barber 2001; Campbell et al. 2003).

Environmental conditions may be important for bryophyte colonization. In a greenhouse experiment, Li \& Vitt (1994) showed that Aulacomnium palustre established quickly on bare peat, regardless of nutrient levels, whereas Polytrichum strictum and Sphagnum angustifolium exhibited a lag in establishment, presumably due to inadequate environmental conditions. Campeau \& Rochefort (1996) observed greater regeneration of $S$. angustifolium, S. magellanicum and S. capillifolium under wetter conditions in a greenhouse study, while $S$. fuscum showed no response to water table manipulation, suggesting the environmental response is species specific.

This study examines bryophyte colonization in a continental bog following wildfire. To this end, an experimental field design was used to address three questions: 1) is there a significant degree of colonization soon - 2 years - after fire, (2) is colonization limited by dispersal (does the application of diaspores increase colonization), and (3) do colonizing Sphagnum and true moss species occur independently of each other (stochastic colonization) or does facilitation occur?

\section{Methods}

Study site

This study was conducted at Crow Lake bog $\left(55^{\circ} 80^{\prime} 1 " \mathrm{~N}\right.$ $\left.113^{\circ} 19^{\prime} 5^{\prime \prime} \mathrm{W}\right)$ located ca. $150 \mathrm{~km}$ south of Fort McMurray, Alberta, Canada. This bog (> 100 ha) was extensively burned in the 2002 Crow Lake fire (Alberta Sustainable Resource Development, Edmonton, Alberta, Canada), with no visible living bryophytes, shrubs, or trees (Picea mariana) remaining post-fire. Combustion severity was heterogeneous, preserving some of the microtopographic gradient through the study site. Lightly burned hummocks were interspersed among more frequent and more severely burned hollows in and approximately 20\%:80\% ratio through the study area. The burned area used for this study is located ca. $20 \mathrm{~m}$ from an unburned utility cut-line through the bog and $70 \mathrm{~m}$ from unburned, intact portions of the bog.

\section{Experimental design}

In June 2003, a randomly placed transect was established through the burned bog, along which 27 sampling points were randomly assigned laterally from the transect, with two random numbers designating the north-south and east-west coordinates. At each sampling point, a 23 $\mathrm{cm} \times 28 \mathrm{~cm}$ plot was established on the nearest high and low microtopographic position, resulting in 54 sample plots in total along a ca. 100-m long transect. Plots were randomly assigned to one of nine treatments including a control (Table 1) for both the high and low positions, with three replicates per treatment $\times$ position combination. For all plots, the top $5 \mathrm{~cm}$ of peat was removed as an intact mat from the peat surface and taken to the lab.

Prior to removing surface peat from the sample plots, collections of abundant, live bryophytes (Sphagnum fuscum, S. magellanicum, S. angustifolium, Polytrichum strictum, and Aulacomnium palustre) were collected from the unburned portions of Crow Lake bog.

Table 1. Fragment addition treatment design. Each treatment was randomly assigned to three high and low microtopographic positions.

\begin{tabular}{|c|c|}
\hline $\begin{array}{l}\text { Treatment } \\
\text { code }\end{array}$ & Application \\
\hline $\mathrm{AO}$ & Sphagnum angustifolium fragments only; autoclaved \\
\hline AP & $\begin{array}{l}\text { S. angustifolium and Polytrichum strictum/Aulacomnium palustre } \\
\text { fragments; autoclaved }\end{array}$ \\
\hline $\mathrm{AM}$ & S. angustifolium and S. magellanicum fragments; autoclaved \\
\hline FO & S. fuscum fragments only; autoclaved \\
\hline FP & S. fuscum and $P$. strictum/A. palustre fragments; autoclaved \\
\hline FM & S. fuscum and S. magellanicum fragments; autoclaved \\
\hline PO & P. strictum/A. palustre fragments only; autoclaved \\
\hline $\mathrm{SC}$ & Sterilized - No fragments; autoclaved \\
\hline $\mathrm{NC}$ & Natural control - No fragments; not autoclaved \\
\hline
\end{tabular}


Sphagnum fuscum, S. magellanicum and S. angustifolium are the dominant Sphagnum species in western Canadian bogs and represent the dominant vegetation of hummocks, mid-hummocks, and hollows, respectively (Vitt 1990; Gignac et al. 1991; Gignac 1992; Benscoter et al. 2005). Polytrichum strictum and Aulacomnium palustre are prevalent true mosses found in bogs and have been known to colonize bare and burned peat ( $\mathrm{Li} \&$ Vitt 1994; Zoltai et al. 1998). The top $3 \mathrm{~cm}$ of the plants were collected and homogenized using a food processor to provide fragments $(1-2 \mathrm{~cm})$ for addition to the treatment plots.

Peat samples from the natural control plots were returned to their original position, allowing growth of new individuals to originate from the diaspore bank, dispersed diaspores, and remaining surface moss fragments. All other peat samples were autoclaved $\left(121^{\circ} \mathrm{C}\right.$ and 27 Bar) to destroy the diaspore bank and then returned to their original position. The sterilized-no fragment treatment allowed re-establishment from dispersed diaspores only. The remaining sterilized plots received ca. 250-ml of moss fragments to the peat surface to achieve uniform cover of the sample plot, either of a single species (Sphagnum fuscum, S. angustifolium or Polytrichum strictum) or an equal mixture of two species in accordance with the plot's assigned treatment.

In October 2005 (28 months later), the plots were assessed for species cover using a sampling grid with $594(22 \times 27) 1 \mathrm{~cm} \times 1 \mathrm{~cm}$ squares. Occurrence by species occupying $>50 \%$ of a grid square was recorded for each $1-\mathrm{cm}^{2}$ grid square within the sample plot and converted to percent cover by species. A second transect (natural transect) was established parallel to the first transect and species cover was assessed for 54 random plots to assess whether the treatments had an effect greater than the background. These plots were not evenly split between high and low microtopographic positions as in the fragment addition transect.

\section{Statistical analyses}

One way $t$-tests were performed to determine if there was significant establishment of the ground layer for each transect and species compared to a hypothetical scenario with no recolonization of the ground layer. Although the data were not normally distributed, a parametric approach was used due to difficulty in assigning a hypothetical mean rank that was ecologically meaningful. The sample variances were homogeneous and the general linear model used is robust with respect to population normality, being only slightly affected by even considerable deviations, especially as sample size increases (Zar 1999). The fragment addition and natural transects were then compared using one-way ANOVAs to detect differences in total cover and cover by species.

For all other analyses, only the fragment addition transect data were used. The effectiveness of treatments within the transect were compared using a three-way ranked ANOVA assessing the effects of treatment, position, and species on total cover. A separate two-way ranked ANOVA was performed by species to examine species-specific effects of treatment and position. The results of the ANOVAs were compared using Tukey's Honestly Significant Difference (HSD) a-posteriori comparisons.

To assess the independence of species occurrence within each transect, plots were scored based on the presence or absence of true mosses (Polytrichum strictum or Aulacomnium palustre) and Sphagnum mosses ( $S$. fuscum, S. angustifolium, or S. magellanicum). The presence/absence data were placed into $2 \times 2$ contingency tables and analysed using $\chi^{2}$ analyses. Because of low frequencies, Fisher's exact test option was used. McNemar's tests were also performed to test whether the proportional occurrence of Sphagnum mosses was equal to that of true mosses. All statistical analyses were performed in SAS v 9.1 (SAS Institute, Cary, NC 2003).

\section{Results}

Overall, a significant amount of ground layer establishment was found in the fragment addition $(t=3.5, d f$ $=53, p=0.001)$ and natural transect $(t=5.7, d f=53, p$ $<0.001)$. Both transects had similar species-specific ground layer establishment, with Sphagnum angustifolium and Polytrichum strictum cover being significantly different than the hypothetical situation of no ground layer colonization, Sphagnum fuscum and $S$. magellanicum showed no significant colonization.

No significant difference in mean total ground cover was found between the natural and fragment addition transects $\left(F_{1,106}=1.7 ; p=0.194\right)$. Polytrichum strictum, S. magellanicum, $S$. fuscum and $S$. angustifolium had similar abundance in the natural $(9 \pm 13 \%, 2 \pm 6 \%, 2 \pm$ $3 \%$, and $1 \pm 4 \%$, respectively) and fragment addition transects $(11 \pm 23 \%, 0 \pm 4 \%, 1 \pm 4 \%$, and $1 \pm 3 \%$, respectively).

Within the fragment addition transect, there was a significant interaction of treatment $\times$ species $\left(F_{24,144}=\right.$ $2.0 ; p=0.008)$ and position $\times$ species $\left(F_{3,144}=0.9 ; p<\right.$ $0.001)$. In general, Polytrichum strictum abundance was greater than Sphagnum mosses (Table 2) and at lower microtopographic positions (Fig. 1), and with the exception of $S$. angustifolium abundance in the ' $S$. angustifolium only' treatment, Sphagnum moss abundance was not significantly greater than zero (Table 2). 
Table 2. Mean percent cover $\pm \operatorname{SD}(n=6)$ for treatment (Table $1) \times$ species $(\mathrm{POLY}=P$. strictum $; \mathrm{ANGU}=$ Sphagnum angustifolium $; \mathrm{FUSC}=S$. fuscum $; \mathrm{MAG}=S$. magellanicum $)$ combinations within the fragment addition transect. Values with different letter labels have significantly different mean ranks (Tukey's $\mathrm{HSD}_{0.05,22,144}=65.81$ ).

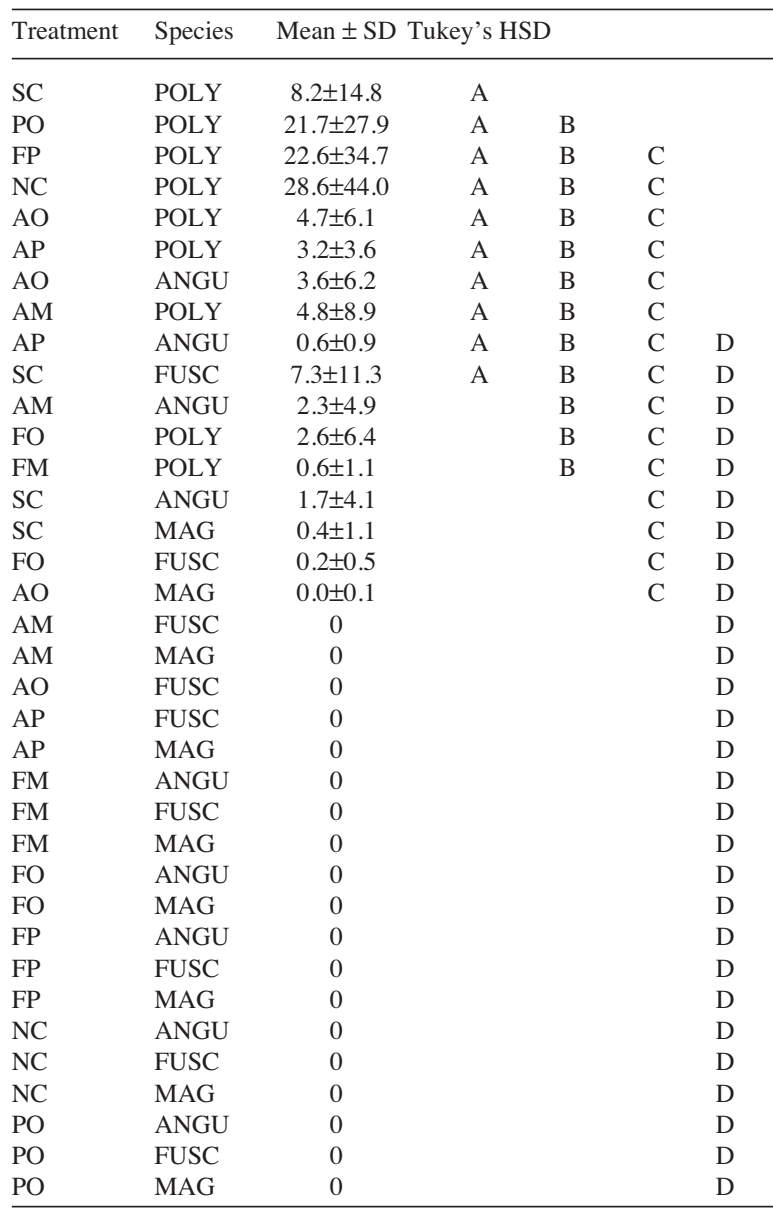

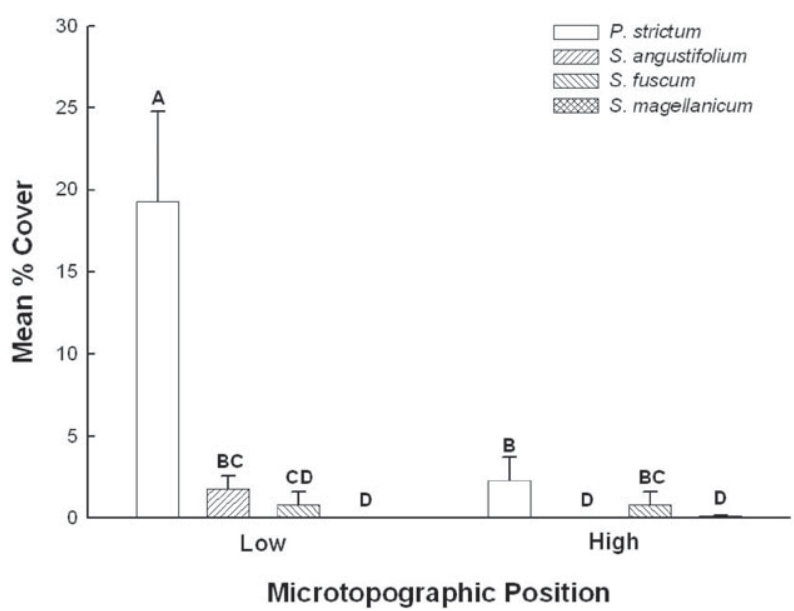

Fig. 1. Mean percent cover \pm SE for four species at low and high relative microtopographic positions along the fragment addition transect. Bars with different labels have significantly different mean ranks (Tukey's $\mathrm{HSD}_{0.05,8,144}=26.03$ ).
While $72 \%$ of plots with $P$. strictum fragments added were successfully colonized (Fig. 2), P. strictum abundance was not significantly greater than the control plots (Fig. 3), nor were the abundances of the Sphagnum species. Sphagnum angustifolium was more abundant at low microtopographic positions $\left(F_{1,36}=9.23 ; p=\right.$ $0.0004)$, as was Polytrichum strictum ( $\mathrm{F}_{1,36}=35.34 ; p$ $<0.0001)$. Sphagnum fuscum and S. magellanicum showed no effect of treatment or position.

True mosses, particularly Polytrichum strictum, dominate the bog soon following fire. Polytrichum strictum overwhelmingly dominated the fragment addition and natural transects in frequency of occurrence and abundance. Sphagnum mosses rarely occurred in the absence of true mosses and only occurred in approximately one-third of the plots occupied by true mosses. Fisher's $\chi^{2}$ analysis of the $2 \times 2$ contingency table showed independence of the species occurrence frequencies for the natural transect $(F=9, d f=1, p=$ 0.0814; Table 3), but not for the fragment addition transect $(F=21, d f=1, p=0.0039$ : Table 3). McNemar's test showed the proportional occurrence of true mosses was greater than Sphagnum mosses for the fragment addition $(S=23, d f=1, p<0.0001)$ and natural transect $(S=24.14, d f=1, p<0.0001)$.

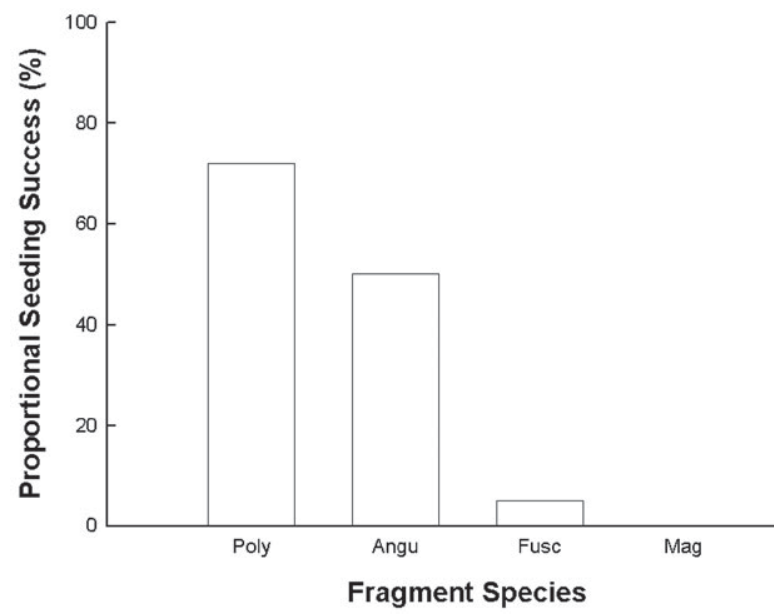

Fig. 2. Proportion of plots with addition of Polytrichum strictum (Poly; $n=18$ ), Sphagnum angustifolium (Angu; $n=18$ ), $S$. fuscum (Fusc; $n=18$ ), or S. magellanicum (Mag; $n=12$ ) fragments in which the applied species occurred. 


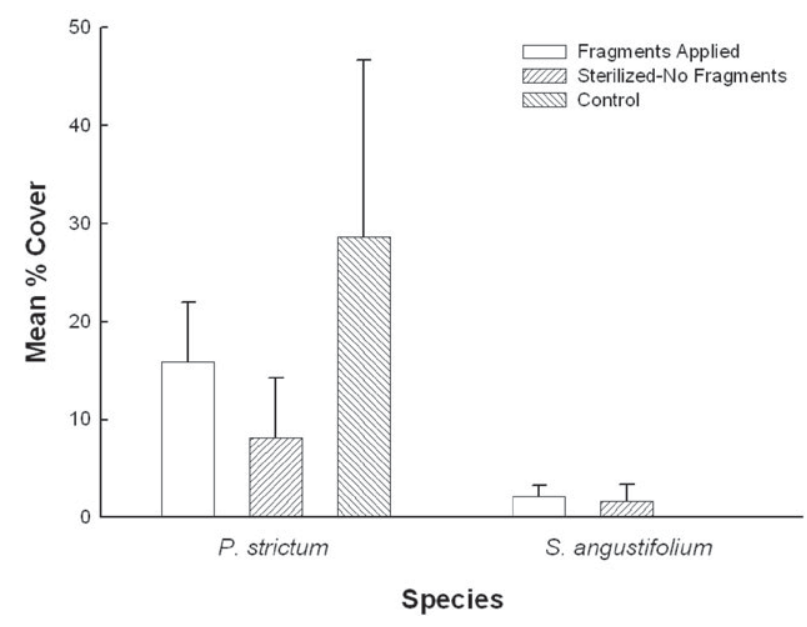

Fig. 3. Mean percent cover \pm SE for Polytrichum strictum and Sphagnum angustifolium in fragment addition $(n=18)$, sterilized-no fragment $(n=6)$, and control $(n=6)$ plots.

\section{Discussion}

While the ground layer vegetation response to fire is relatively slow in bogs, a significant degree of re-establishment was found after two years. Availability of diaspores does not appear to limit species establishment post-fire. Diaspore availability was sufficient to result in equal or greater occurrence and abundance of species in natural and control plots compared to fragment addition plots, indicating aerial dispersed diaspores were abundantly available to initiate colonization. While the study site was relatively close to unburned bog areas (ca. 70-m), similar diaspore availability should be found at even greater distances. Campbell et al. (2003) and Ross-Davis and Frego (2004) found high aerial diaspore dispersal ability of mosses in mined peatlands and boreal forests of Canada, respectively, suggesting diaspore availability is not limiting and does not determine colonization patterns (Campbell et al. 2003).

Post-fire ground layer colonization was spatially limited, with the majority of plant growth occurring in small, isolated patches on the landscape. Edaphic conditions, particularly wetness, are more likely responsible for colonization success (Campeau \& Rochefort 1996), as illustrated by the greater occurrence and abundance of species at low microtopographic positions. This contradicts the findings of Smolders et al. (2003) who suggested the lack of hummock and lawn Sphagnum species colonization of post-harvest peat was due to colonization problems, not a lack of suitable conditions, illustrating that conclusions drawn based on bare peat are variable and may not be applicable to a natural disturbance situation.

Polytrichum strictum and other true mosses seem to
Table 3. Contingency tables of true moss and Sphagnum moss occurrence for 54 plots in the fragment addition (a) and natural (b) transect.

\begin{tabular}{llccc}
\hline a. & \multicolumn{3}{c}{ True moss } \\
Sphagnum & & Present & Absent & Total \\
\cline { 2 - 5 } Moss & Present & 10 & 0 & 10 \\
& Absent & 23 & 21 & 44 \\
\cline { 2 - 5 } & Total & 33 & 21 & 54 \\
b. & & & True moss & \\
& & & Absent & Total \\
Sphagnum & Present & & 1 & 18 \\
Moss & Absent & 27 & 9 & 36 \\
\cline { 2 - 5 } & Total & 44 & 10 & 54 \\
\hline
\end{tabular}

represent classically termed ' $r$-selected' early colonizers, which arrive and colonize quickly post-disturbance (MacArthur \& Wilson 1967). These species may then modify the environment and facilitate Sphagnum colonization, possibly by stabilizing the bare peat surface or preventing frost heaving (Groeneveld \& Rochefort 2005). The greater occurrence of Sphagnum mosses in association with true mosses than without suggests Sphagnum may require microhabitat modification post-fire before it can successfully establish. However, the mechanism or presence of facilitation was not explicitly examined in this study. Although we did not observe the Aulacomnium palustre phase found by Li \& Vitt (1994), this may be due to the timing of sampling, as their study looked at the first 120 days of recolonization.

As succession progresses and Sphagnum mosses become more abundant, competitive interactions may be more important. Polytrichum strictum cover is far greater in this early post-fire site compared to more mature bogs (Benscoter unpublished data), suggesting the realized niche and thereby proportional occurrence of $P$. strictum may be greatly reduced as Sphagnum assumes dominance of the ground layer over time, although long term monitoring will be required to support this theory.

In summary, while only one bog was examined, these data lay the foundation for understanding the reestablishment of the ground layer in boreal bogs and identify microhabitat and species life history strategy, not diaspore availability, as the factors determining patterns of post-fire ground layer recolonization of bogs. Because variable fire severity (Benscoter \& Wieder 2003) and microtopography (Vitt 1990) promote heterogeneous microhabitat availability, it is important to understand these recolonization patterns when determining the post-fire recovery trajectory of boreal bogs. 
Acknowledgements. Thanks to Dr. Dale Vitt, Dr. David Gibson, and the reviewers for their comments, Bin Xu for help with data collection, and Meanook Research Station (U. Alberta) for use of their facilities. Funding was provided by National Science Foundation grant (IBN 021233 to D.H. Vitt and R.K. Wieder) and a US Environmental Protecton Agency STAR fellowship and Society of Wetland Scientists student research grant to BW Benscoter.

\section{References}

Benscoter, B. \& Wieder, R.K. 2003. Variability in organic matter lost by combustion in a boreal bog during the 2001 Chisholm fire. Can. J. For. Res. 33: 2509-2513.

Benscoter, B., Wieder, R.K. \& Vitt, D.H. 2005. Linking microtopography with post-fire succession in bogs. J. Veg. Sci. 16: 453-460.

Brokaw, N. \& Busing, R.T. 2000. Niche versus chance and tree diversity in forest gaps. Trends Ecol. Evol. 15: 183-188.

Campbell, D.R., Rochefort, L. \& Lavoie, C. 2003. Determining the immigration potential of plants colonizing disturbed environments: the case of milled peatlands in Quebec. $J$. Appl.Ecol. 40: 78-91.

Campeau, S. \& Rochefort, L. 1996. Sphagnum regeneration on bare peat surfaces: field and greenhouse experiments. $J$. Appl. Ecol. 33: 599-608.

Clymo, R.S. \& Duckett, J. 1986. Regeneration of Sphagnum. New Phytol. 102: 589-614.

Connell, J.H. \& Slatyer, R.O. 1977. Mechanisms of succession in natural communities and their role in community stability and organization. Am. Nat. 111: 1119-1144.

Cottenie, K. 2005. Integrating environmental and spatial processes in ecological community dynamics. Ecol. Lett. 8: 1175-1182.

Faubert, P.\& Rochefort, L. 2002. Response of peatland mosses to burial by wind-dispersed peat. Bryologist 105: 96-103.

Gignac, L.D. 1992. Niche structure, resource partitioning, and species interactions of mire bryophytes relative to climatic and ecological gradients in western Canada. Bryologist 95: 406-418.

Gignac, L.D., Vitt, D.H., Zoltai, S.C. \& Bayley, S.E. 1991. Bryophyte response surfaces along climatic, chemical, and physical gradients in peatlands of western Canada. Nova Hedw. 53: 27-71.

Groeneveld,E.V.G.\& Rochefort,L. 2005. Polytrichum strictum as a solution to frost heaving in disturbed ecosystems: A case study with milled peatlands. Restor. Ecol. 13: 74-82.

Grubb, P.J. 1977. The maintenance of species richness in plant communities: the importance of the regeneration niche. Biol. Rev. 52: 107-145.

Hubbell, S.P. 2001. The unified theory of biodiversity and biogeography. Princeton University Press, Princeton, NJ, US.

Hubbell, S.P. 2005. Neutral theory in community ecology and the hypothesis of functional equivalence. Funct. Ecol. 19: 165-172.

Hurtt, G.C. \& Pacala, S.W. 1995. The consequences of recruitment limitation. Reconciling chance, history, and competi- tive differences between plants. J. Theor. Biol. 176: 1-12.

Hutchinson, G. 1958. Concluding remarks. Cold Spring Harbor Symp. Quant. Biol. 22: 415-427.

Kimmerer, R.W. \& Young, C.C. 1996. Effect of gap size and regeneration niche on species coexistence in bryophyte communities. Bull. Torrey Bot. Club 123: 16-24.

Kneitel, J.M. \& Chase, J.M. 2004. Trade-offs in community ecology: linking spatial scales and species coexistence. Ecol. Lett. 7: 69-80.

Li, Y.\& Vitt, D.H. 1994. The dynamics of moss establishment: temporal responses to nutrient gradients. Bryologist 97: 337-365.

MacArthur, R.H. \& Wilson, E.O. 1967. The theory of island biogeography. Princeton University Press, Princeton, NJ, US.

Ross-Davis, A.L. \& Frego, K.A. 2004. Propagule sources of forest floor bryophytes: spatiotemporal compositional patterns. Bryologist 107: 88-97.

Rydin, H. \& Barber, K.E. 2001. Long-term and fine-scale coexistence of closely related species. Folia Geobot. 36: 53-61.

Smolders, A.J.P., Tomassen, H.B.M., van Muliekom, M., Lamers, L.P.M. \& Roelofs, J.G.M. 2003. Mechanisms involved in the re-establishment of Sphagnum-dominated vegetation in rewetted bog remnants. Wet. Ecol. Manage. 11: 403-418.

Tilman, D. 1982. Resource competition and community structure Princeton University Press, Princeton, NJ, US.

Tilman, D. 1994. Competition and biodiversity in spatially structured habitats. Ecology 75: 2-16.

Turetsky, M.R., Amiro, B.D., Bosch, E. \& Bhatti, J.S. 2004. Historical burn area in western Canadian peatlands and its relationship to fire weather indices. Global Biogeochem. Cycles 18: GB4014.

Vitt, D.H., Marsh, J.E., \& Bovey, R.B. 1988. Mosses, lichens \& ferns of northwest North America. Lone Pine Publishing, Edmonton, Alberta, CA.

Vitt, D.H. 1990. Growth and production dynamics of boreal mosses over climatic, chemical, and topographic gradients. Bot. J. Linn. Soc. 104: 35-59.

Whittaker, R.H. 1972. Evolution and measurement of species diversity. Taxon 21: 213-251.

Zar, J.H. 1999. Biostatistical analysis, 4th. ed. Prentice Hall, Upper Saddle River, NJ, US.

Zoltai, S.C., Morrissey, L.A., Livingston, G.P.\& de Groot, W.J. 1998. Effects of fires on carbon cycling in North American boreal peatlands. Environ. Rev. 6: 13-24.

Received 20 February 2006; Accepted 2 July 2006; Co-ordinating Editor: B. Collins. 